\title{
Use of angiotensin-converting-enzyme inhibitors or angiotensin-receptor blockers and cancer risk: a meta-analysis of observational studies
}

\author{
Chan Yoon MD, Hyun-Sik Yang MD, Inpyo Jeon MD, Yoosoo Chang MD, Sang Min Park MD PhD
}

\begin{abstract}
Background: Epidemiologic studies have reported inconsistent findings regarding the association between the use of angiotensinconverting-enzyme (ACE) inhibitors or angiotensin-receptor blockers and the risk of cancer. We performed a meta-analysis of observational studies to assess the association.

Methods: We searched MEDLINE, EMBASE and the Cochrane Library to identify studies through January 2011. Two evaluators independently reviewed and selected articles of cohort and case-control studies on the basis of predetermined selection criteria.
\end{abstract}

Results: Of 3970 screened articles, 12 cohort studies and 16 case-control studies were selected for analysis. We found no significant association between the use of ACE inhibitors or angiotensin-receptor blockers and the overall risk of cancer (relative risk [RR] 0.96, $95 \%$ confidence interval $[\mathrm{Cl}]$ 0.90-1.03). We found a decreased risk of cancer associated with use of either medication when we restricted the analyses to cohort and nested case-control studies (RR $0.90,95 \% \mathrm{Cl} 0.83-$ 0.97) or to studies with long-term follow-up of more than five years (RR $0.89,95 \% \mathrm{Cl} 0.83-$ $0.96)$. In the subgroup meta-analyses by cancer site, a decreased risk was identified for esophageal cancer, whereas an increased risk was found for melanoma and kidney cancer.

Interpretation: No significant association was found between the use of ACE inhibitors or angiotensin-receptor blockers and overall risk of cancer. A possible beneficial effect associated with use of either medication was suggested in sensitivity analyses, including those of studies with long-term follow-up. Large randomized controlled trials with long-term follow-up are needed to specifically test the effect of each of these medications on the risk of cancer.
$\mathrm{R}$ ecent meta-analyses have shown a possible increased risk of cancer associated with angiotensin-receptor blockers used alone or combined with angiotensin-convertingenzyme (ACE) inhibitors. ${ }^{1,2}$ Despite the strong internal validity of randomized controlled trials (RCTs) used in prior meta-analyses, it is difficult to interpret these results because of the short duration of follow-up for cancer detection. ${ }^{3} \mathrm{~A}$ previous retrospective cohort study with a mean follow-up of 6.6 years showed that the use of ACE inhibitors was associated with a significantly decreased risk of overall cancer, and cancer of the lung, breast and female reproductive organs and smoking-related cancers. ${ }^{4}$ Despite the inconsistent results reported by previous observational studies regarding this issue, ${ }^{4-35}$ we conducted a meta-analysis of cohort and casecontrol studies to assess the association between use of these medications and the risk of cancer.

\section{Methods}

\section{Literature search}

We searched MEDLINE, EMBASE and the Cochrane Central Register of Controlled Trials (CENTRAL) in the Cochrane Library up to January 2011 using common keywords related to ACE inhibitors, angiotensin-receptor blockers and cancer. The search terms were as follows: "angiotensin-converting enzyme inhibitor" or "angiotensin receptor blocker" or trade names of the medications AND "cancer" or "carcinoma" or "neoplasm" or "malignancy" or names of specific types of cancer. (For details about the search strategy, see Appendix 1, at www.cmaj.ca/lookup/suppl/doi:10.1503 /cmaj.101497/-/DC1.) We also reviewed the bibliographies of relevant articles to identify additional publications. Studies were restricted to those involving humans.
Competing interests: Sang Min Park has received a grant from the National research Foundation of Korea. No other competing interests were declared by the authors.

This article has been peer reviewed.

Correspondence to: Dr. Sang Min Park, smpark.snuh@gmail.com

CMAJ 2011. DOI:10.1503 /cmaj.101497 


\section{Selection of relevant studies}

Two of us (C.Y., H.Y.) independently evaluated the eligibility of all studies retrieved from the databases on the basis of the predetermined selection criteria (Appendix 2, available at www .cmaj.ca/lookup/suppl/doi:10.1503/cmaj.101497 /-/DC1). Disagreements between evaluators were resolved by discussion or in consultation with a third author (S.M.P.).

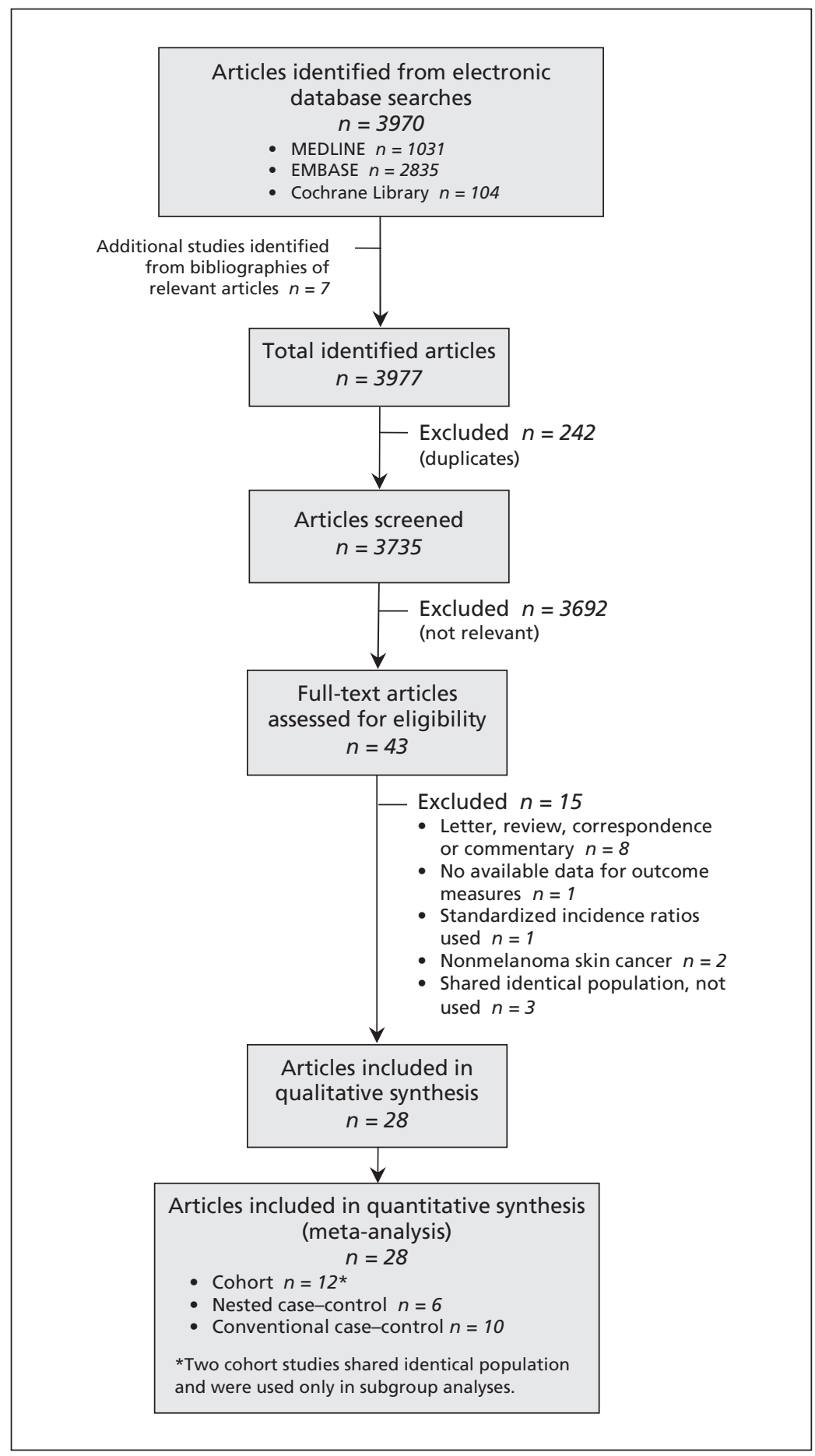

Figure 1: Identification of relevant cohort studies and case-control studies for inclusion in the meta-analysis.

\section{Data synthesis}

To compute a pooled relative risk (RR) with 95\% confidence interval (CI), we used the RRs (or odds ratios) and 95\% CIs that were adjusted for most confounders. Because the incidence of cancer is generally low, we assumed that we could ignore the distinction among the various measures of relative risk in our study. ${ }^{36}$ If estimates for more than one type of cancer were reported in a single study, we asked the authors for the combined estimate. If the combined estimate was not provided by the authors, we used the estimates from the largest number of cancer cases. If the outcome measures were unsuitable for meta-analysis, we used data from a $2 \times 2$ table to recalculate crude estimates.

Because of known clinical and methodologic heterogeneity of the studies used in analyses, we report pooled RRs and 95\% CIs calculated from the random-effects model using the method described by DerSimonian and Laird. ${ }^{37}$

We performed sensitivity analyses to examine effect sizes when only the following types of studies were included: studies that reported use of ACE inhibitors; studies that reported use of either ACE inhibitors or angiotensin-receptor blockers; studies that reported adjusted estimates; studies that reported estimates for any cancer development; cohort studies and nested case-control studies; and studies with long-term follow-up. Because cohort studies and nested case-control studies are known to have less recall bias, selection bias and temporal ambiguity than conventional case-control studies, they are considered to have higher methodologic quality. ${ }^{38}$ Therefore, we excluded conventional case-control studies and used only cohort or nested case-control studies in the sensitivity analyses. Studies with long-term follow-up included those that had a mean follow-up of more than five years, as well as studies that reported estimates from a subgroup with a follow-up of more than five years.

We used random-effects metaregression analysis to determine whether there was a relation between the risk of cancer and potential effect modifiers, including study design and five predetermined quality-assessment items (representativeness of the cohort or cases; ascertainment of exposure; exclusion of outcome of interest at enrolment; assessment of outcome; and control of study for age, cigarette smoking, body mass index and diabetes mellitus). Two of us (C.Y., H.Y.) independently assessed the potential effect modifiers, and disagreements were re solved through discussion.

We conducted subgroup meta-analyses by study design and by type of cancer. We investi- 


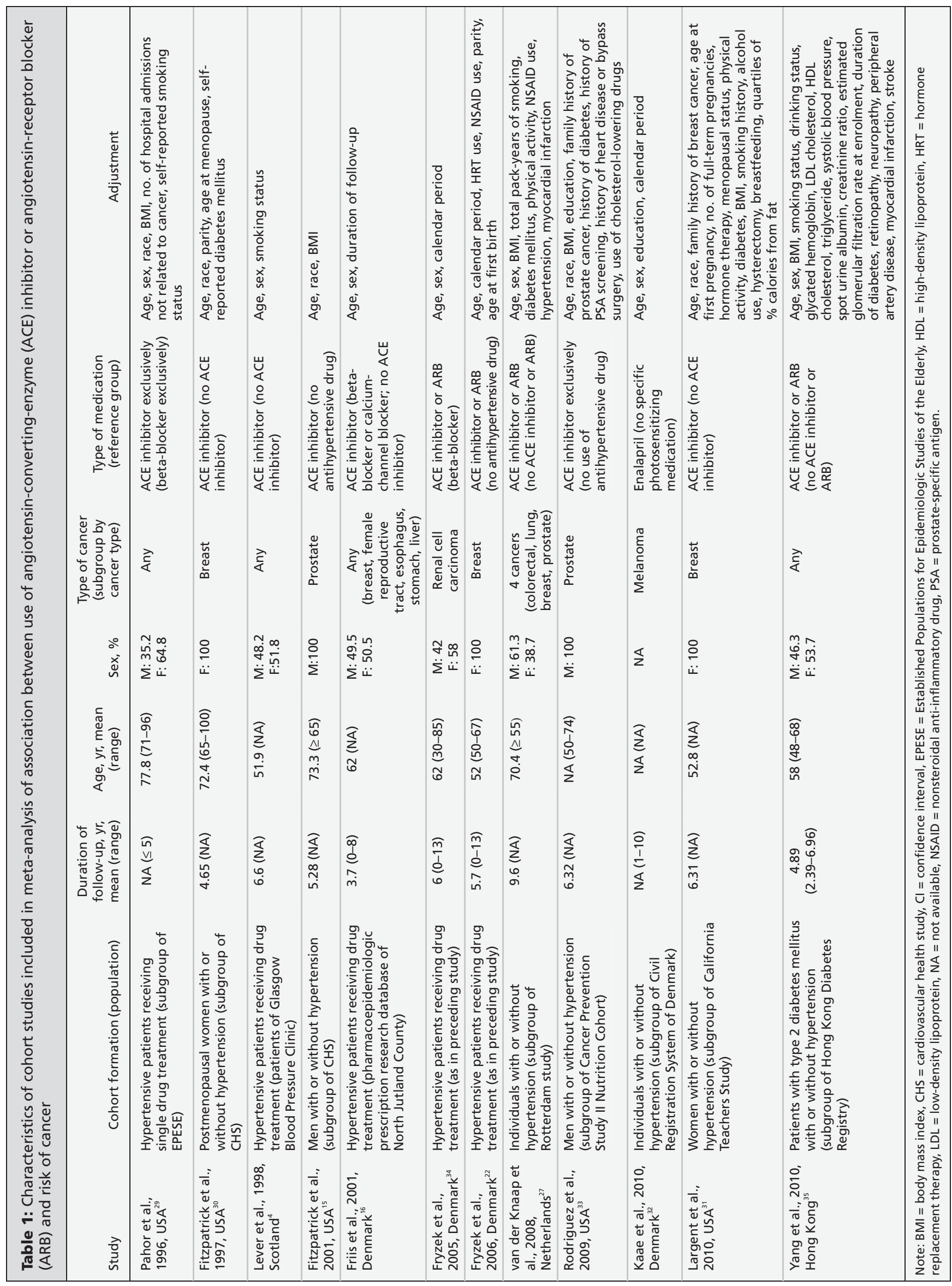




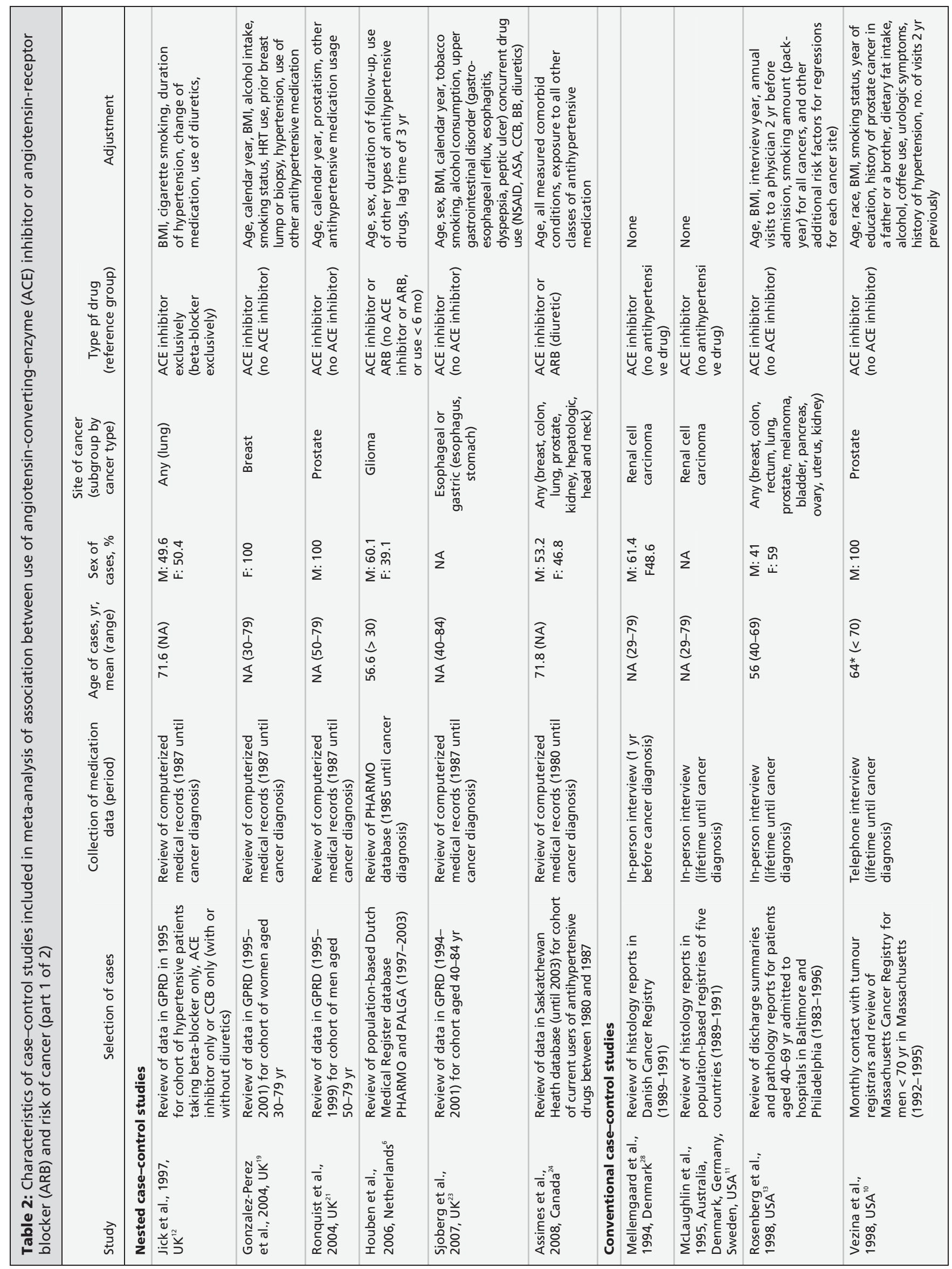




\begin{tabular}{|c|c|c|c|c|c|c|c|c|}
\hline 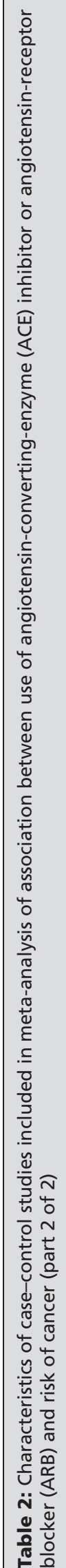 & 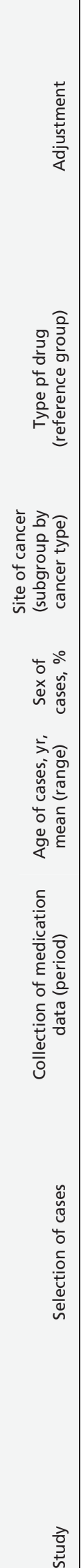 & 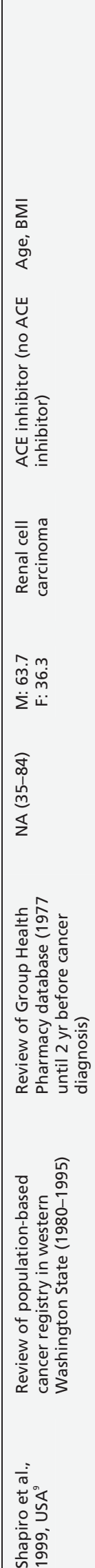 & 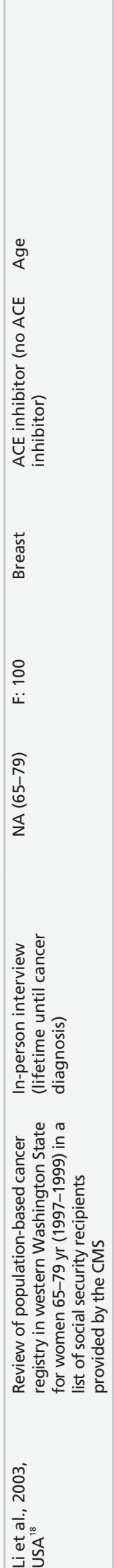 & 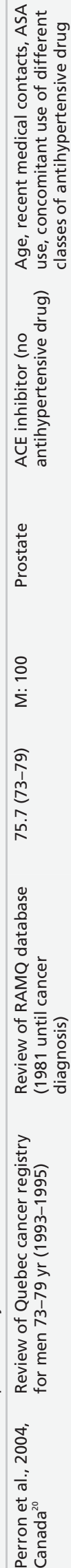 & 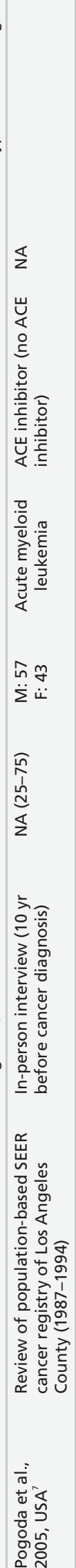 & 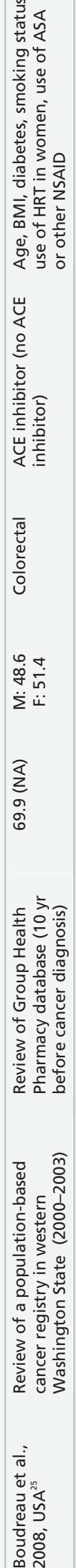 & 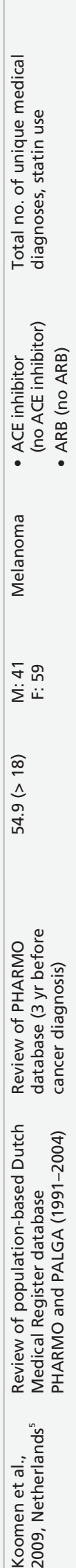 & 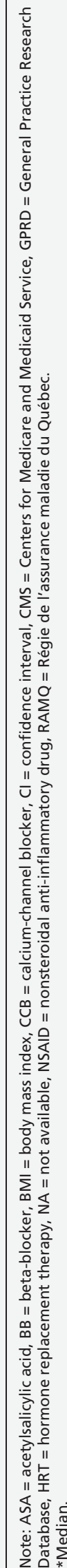 \\
\hline
\end{tabular}

gated the effect of the use of ACE inhibitors or angiotensin-receptor blockers on site-specific cancers separately using all studies, cohort or nested case-control studies, and studies with long-term follow-up. We defined smokingrelated cancers as cancers with a dose-response relation between smoking and cancer risk. ${ }^{39-41}$

\section{Results}

\section{Study characteristics}

Of the 3970 articles identified, we selected 12

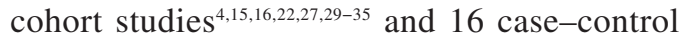
studies $^{5-7,9-13,18-21,23-25,28}$ for the analyses (Figure 1). Two of the cohort studies were used only in the subgroup analyses because they shared a study population (Appendix 2).22,34 We contacted the authors of six articles to ask for the combined estimates for total drug users; ;, ${ }^{5,2,21-23,34}$ the authors of three articles provided these adjusted estimates. ${ }^{19,21,23}$ The outcome measures were unsuitable for meta-analysis in two case-control studies; ${ }^{11,28}$ we therefore used data from $2 \times 2$ tables to recalculate the crude estimates.

A total of 3611694 people participated in the 10 cohort studies included in the meta-analyses. The mean duration of follow-up for the total cohort was 5.75 years (range 1-13 years). Seven of the cohort studies reported the total number of participants using ACE inhibitors or angiotensinreceptor blockers ( $n=26912)$ as well as the number in whom cancer developed $(n=1210$, $4.5 \%)^{4,15,16,29-31,35}$

All but 2 of the 16 case-control studies reported the number of cases $(n=27987)$ and controls $(n=119 \text { 879). })^{5,6,9-13,18,19,21,23-25,28}$ The proportion of participants who used an ACE inhibitor or angiotensin-receptor blocker was 7.3\% among the cases and $7.9 \%$ among the controls.

Tables 1 and 2 show the general characteristics of the studies included in the analyses.

The methodologic quality of the studies is summarized in Tables 3 and 4 . All of the studies controlled for age, and about half also controlled for cigarette smoking or body mass index.

The metaregression analysis of the association between potential effect modifiers and the log estimate for the risk of cancer showed a significant difference between cohort or nested casecontrol studies and conventional case-control studies (Appendix 3, available at www.cmaj.ca /lookup/suppl/doi:10.1503/cmaj.101497/-/DC1).

\section{Effect of medication use on risk of cancer}

We found no significant association between the use of ACE inhibitors or angiotensin-receptor blockers and the risk of cancer in the metaanalysis of all of the studies (RR 0.96, 95\% CI 
0.90-1.03) (Table 5). However, significant heterogeneity existed among these studies $\left(I^{2}=\right.$ 60.5). The heterogeneity was due in part to study design and duration of follow-up; it was not due to whether studies evaluated ACE inhibitors alone or combined with angiotensin-receptor blockers, or whether studies evaluated any cancer as opposed to specific cancers.

In the sensitivity analyses, a beneficial effect of the use of ACE inhibitors or angiotensin-receptor blockers on cancer risk was shown when the conventional case-control studies were excluded (RR 0.90, 95\% CI 0.83-0.97) (Table 5). A beneficial effect was also found when the analysis was limited to the 11 studies with long-term follow-up (RR 0.89, 95\% CI 0.83-0.96). ${ }^{4,6,13,15,18,22-24,2,7,3,1,33}$
When the analyses were restricted to studies that investigated the effect of only ACE inhibitors on cancer risk, the 12 cohort and nested case-control studies showed a nonsignificant protective effect (RR 0.93 , 95\% CI $0.86-$ $1.01),{ }^{4,12,15,16,19,21,23,29-33}$ and the 8 studies with longterm follow-up showed a significant protective effect (RR 0.89, 95\% CI 0.80-0.98). ${ }^{4,13,15,18,22,23,3,1,33}$ No significant change was observed when we excluded two studies with crude estimates. ${ }^{11,28}$

In the subgroup analyses by study design (Figure 2), a decreased overall risk of cancer was shown in the analyses of cohort studies (RR $0.87,95 \%$ CI $0.77-0.99$ ) and nested casecontrol studies (RR $0.91,95 \%$ CI $0.85-0.98$ ). A marginally increased risk was shown in the

\begin{tabular}{|c|c|c|c|c|c|}
\hline \multirow[b]{2}{*}{ Study } & \multicolumn{5}{|c|}{ Quality assessment items } \\
\hline & $\begin{array}{l}\text { Representativeness } \\
\text { of the cohort* }\end{array}$ & $\begin{array}{l}\text { Ascertainment of } \\
\text { exposure: secure } \\
\text { record or structured } \\
\text { interview* }\end{array}$ & $\begin{array}{l}\text { Shows that outcome } \\
\text { of interest was not } \\
\text { present at start of } \\
\text { study* }\end{array}$ & $\begin{array}{l}\text { Assessment of } \\
\text { outcome: independent } \\
\text { blind assessment or } \\
\text { record linkage* }\end{array}$ & $\begin{array}{l}\text { Study controls for } \\
\text { age, cigarette } \\
\text { smoking, BMI, } \\
\text { diabetes statust }\end{array}$ \\
\hline Pahor et al., $1996^{29}$ & $\stackrel{-}{-}$ (age > $70 \mathrm{yr})$ & + & + & + & $\begin{array}{c}+++ \\
\text { (age, cigarette } \\
\text { smoking, BMI) }\end{array}$ \\
\hline $\begin{array}{l}\text { Fitzpatrick et al., } \\
1997^{30}\end{array}$ & $\begin{array}{c}- \\
\text { (age }>65 \mathrm{yr})\end{array}$ & + & + & $\begin{array}{c}- \\
\text { (self-report) }\end{array}$ & $\begin{array}{c}\stackrel{++}{(a g e}, \text { diabetes) } \\
\text { (a) }\end{array}$ \\
\hline Lever et al., $1998^{4}$ & + & + & - & + & $\begin{array}{l}\text { (age, cigarette } \\
\text { smoking) }\end{array}$ \\
\hline $\begin{array}{l}\text { Fitzpatrick et al., } \\
2001^{15}\end{array}$ & (age $\left.>-\frac{}{>} 65 \mathrm{yr}\right)$ & + & + & $\stackrel{-}{\text { (self-report) }}$ & $\begin{array}{c}++ \\
\text { (age, BMI) }\end{array}$ \\
\hline Friis et al., $2001^{16}$ & + & + & - & + & $\stackrel{+}{\text { (age) }}$ \\
\hline $\begin{array}{l}\text { Fryzek et al., } \\
2005^{34}\end{array}$ & + & + & - & + & $\stackrel{+}{\text { (age) }}$ \\
\hline $\begin{array}{l}\text { Fryzek et al., } \\
2006^{22}\end{array}$ & + & + & - & + & $\stackrel{+}{\text { (age) }}$ \\
\hline $\begin{array}{l}\text { van der Knaap et } \\
\text { al., } 2008^{27}\end{array}$ & + & + & + & + & $\begin{array}{l}\quad++++ \\
\text { (age, cigarette } \\
\text { smoking, BMI, } \\
\text { diabetes) }\end{array}$ \\
\hline $\begin{array}{l}\text { Rodriguez et al., } \\
2009^{33}\end{array}$ & $\stackrel{-}{-}$ & $\stackrel{-}{\text { (self-report) }}$ & + & $\stackrel{-}{\text { (self-report) }}$ & $\begin{array}{c}+++ \\
\text { (age, BMI, } \\
\text { diabetes) }\end{array}$ \\
\hline Kaae et al., $2010^{32}$ & + & + & + & + & $\begin{array}{c}+ \\
\text { (age) }\end{array}$ \\
\hline $\begin{array}{l}\text { Largent et al., } \\
2010^{31}\end{array}$ & $\begin{array}{c}- \\
\text { (teachers) }\end{array}$ & $\begin{array}{c}- \\
\text { (self-report) }\end{array}$ & - & + & $\begin{array}{l}\text { (age, cigarette } \\
\text { smoking, BMl, } \\
\text { diabetes) }\end{array}$ \\
\hline Yang et al., $2010^{35}$ & $\begin{array}{c}- \\
\text { (patients with } \\
\text { diabetes mellitus) }\end{array}$ & + & + & + & $\begin{array}{l}\quad+++ \\
\text { (age, cigarette } \\
\text { smoking, BMI) }\end{array}$ \\
\hline
\end{tabular}


analysis of the conventional case-control studies (RR 1.14, 95\% CI 1.00-1.31).

In the subgroup meta-analysis of the seven studies that reported estimates for any cancer development, a beneficial effect was found (RR $0.85,95 \%$ CI 0.73-0.98) (Table 6)..$^{4,12,13,16,24,29,35}$ When studies were stratified by site of cancer, a decreased risk of cancer associated with use of ACE inhibitors or angiotensin-receptor blockers was identified for esophageal cancer (RR 0.73,
95\% CI 0.57-0.94) and an increased risk was observed for melanoma (RR 1.09, 95\% CI 1.001.19) and kidney cancer (RR $1.50,95 \%$ CI 1.012.23). Further stratification by excluding conventional case-control studies showed a decreased risk of prostate cancer (RR 0.88, 95\% CI 0.80$0.97)$; the decreased risk of esophageal cancer and the increased risk of melanoma persisted. For kidney cancer, no significant association was found when conventional case-control studies

Table 4: Assessment of the methodologic quality of the case-control studies included in meta-analysis

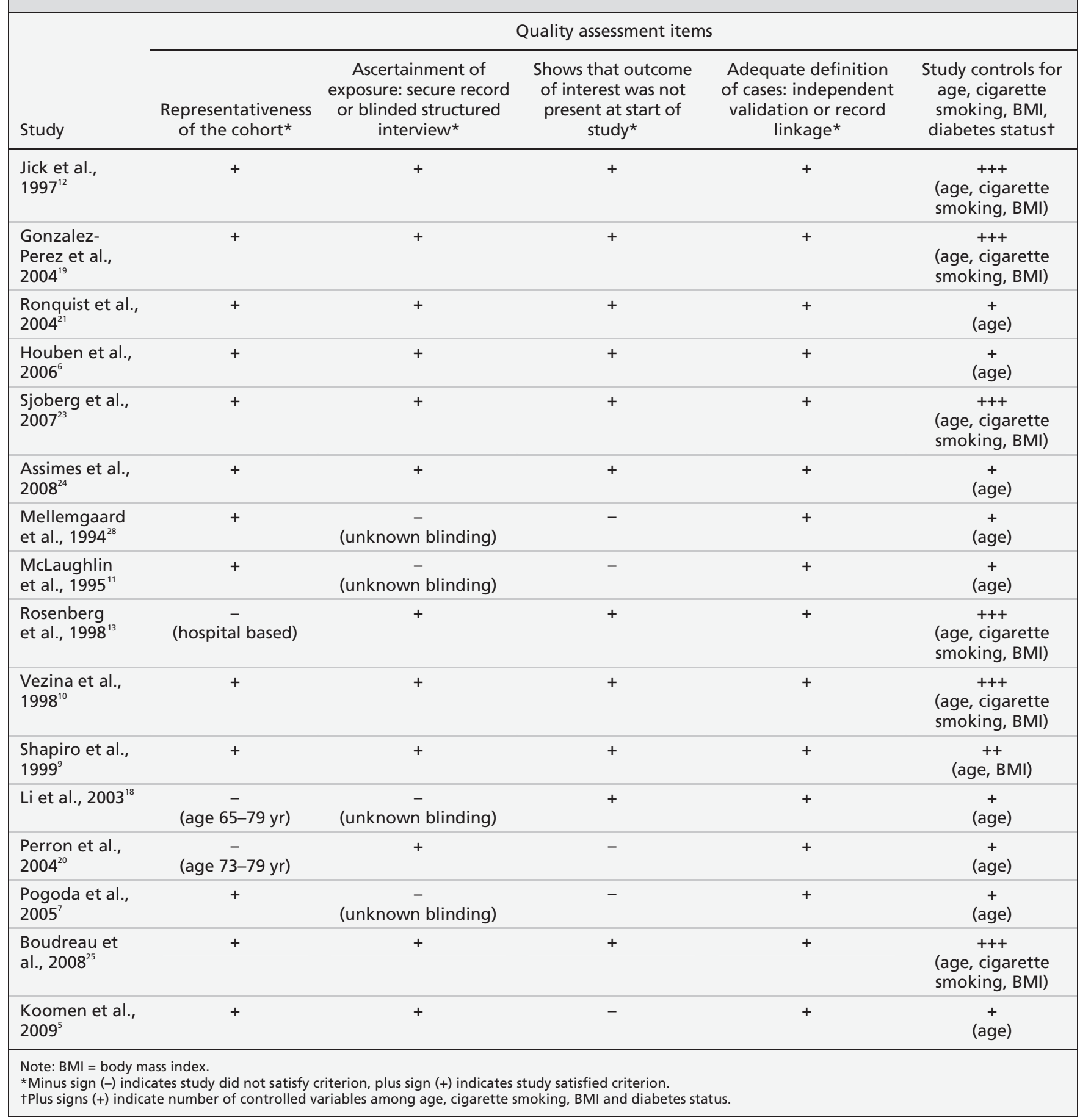




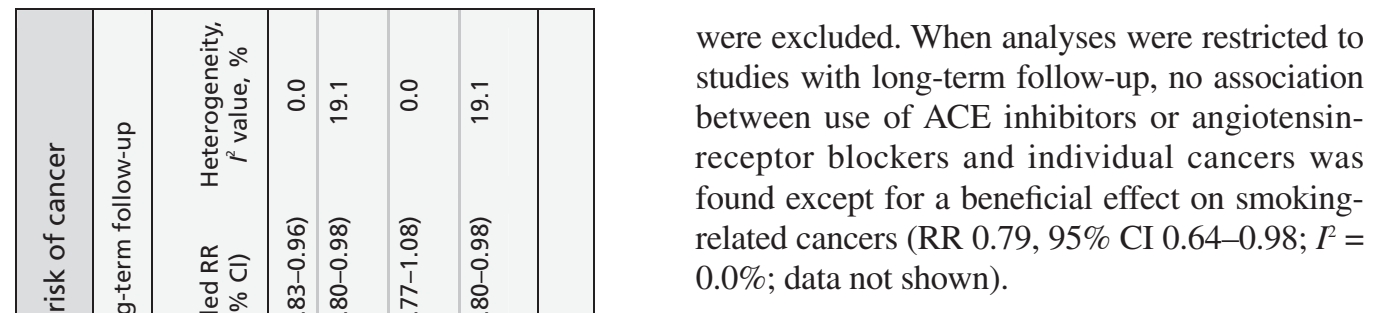

\section{Interpretation}

Our meta-analyses of observational studies showed no significant association between the use of ACE inhibitors or angiotensin-receptor blockers and overall risk of cancer. However, a beneficial effect was shown in sensitivity analyses that included only cohort and nested case-control studies or studies with long-term follow-up.

In the subgroup analysis by site of cancer, we found that use of ACE inhibitors or angiotensinreceptor blockers was associated with a decreased risk of esophageal cancer but an increased risk of melanoma and kidney cancer. When conventional case-control studies were excluded, the analysis showed a decreased risk of esophageal cancer and prostate cancer and an increased risk of melanoma. Moreover, longterm use of ACE inhibitors or angiotensinreceptor blockers was associated with a decreased risk of smoking-related cancers.

The anticancer effect of ACE inhibitors and angiotensin-receptor blockers is thought to be mediated through rennin-angiotensin systemdependent inhibition of angiotensin II levels ${ }^{42}$ as well as increases in bradykinin levels. ${ }^{43}$ Many experimental studies have shown that angiotensin II may affect cancer development through various steps ${ }^{44}$ which can play a role in the process of cancer initiation, progression, ${ }^{45-47}$ invasiveness ${ }^{48,49}$ and metastasis..$^{50}$ Bradykinin that is overly produced by ACE inhibitor use acts on endothelial cells to induce synthesis of prostacyclin and the release of nitric oxide. Both increased prostacyclin and nitric oxide contribute to the anticancer effect of ACE inhibitors by counteracting the action of angiotensin II..$^{42}$ Furthermore, the use of ACE inhibitors has been shown to reduce the tumour volume as well as prevent metastasis in rodent models of common human carcinomas. ${ }^{51-53}$

The most recent and largest meta-analysis of RCTs reported no significant association between the use of ACE inhibitors or angiotensinreceptor blockers and the development of cancer. ${ }^{2}$ However, the duration of follow-up in most of the trials ranged from one to five years. Because events are generally evenly distributed across a trial, mean exposure time to study drugs before cancer diagnosis would be less than three years, which is considered to be too short to 


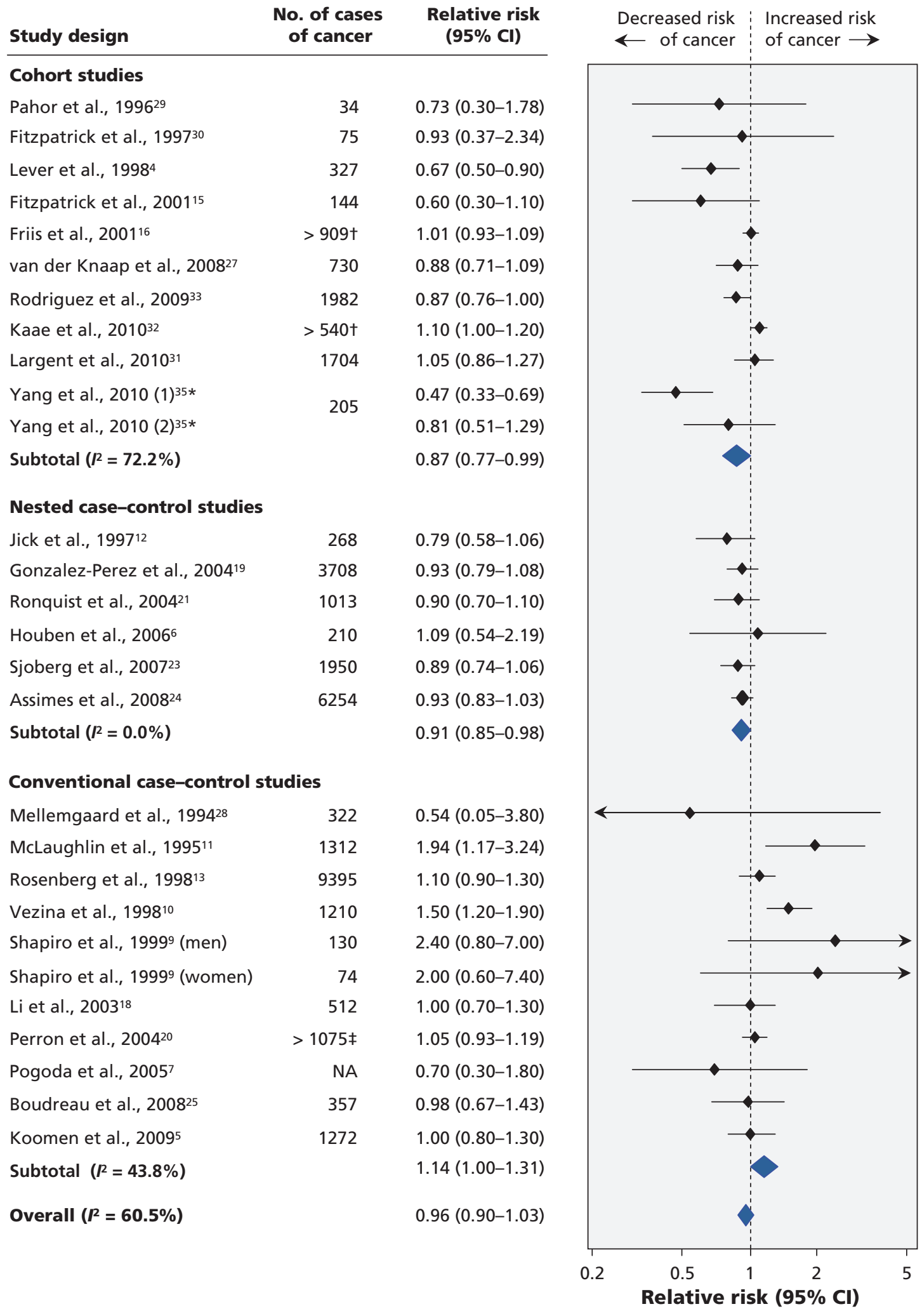

Figure 2: Results of random-effects meta-analysis of association between use of angiotensin-converting-enzyme (ACE) inhibitors or angiotensin-receptor blockers and risk of cancer. A relative risk greater than 1.0 indicates an increased risk for cancer. *Yang and coauthors $^{35}$ reported estimates separately for two groups totalling 205 cases of cancer: those with a leukocyte count of $5.8 \times 10^{9} / \mathrm{L}$ or greater, and those with a lower leukocyte count. tTotal number of cancer cases was higher than the number reported among people using ACE inhibitors or angiotensin-receptor blockers. \#Total number of cancer cases was higher than the number reported among people not using ACE inhibitors or angiotensin-receptor blockers. $\mathrm{Cl}=$ confidence interval, $\mathrm{NA}=$ not available. 
make any meaningful conclusions about the incidence of cancer in humans. ${ }^{3,54}$ Moreover, more than half of the trials used in that meta-analysis involved patients with severe comorbid diseases such as heart failure, chronic kidney disease and coronary artery disease; premature death by comorbidity before cancer development would have affected the results.

By using observational studies in our metaanalysis, we were able to include studies that involved general populations and had longer follow-up periods. The average duration of followup in the cohort studies, for example, was 5.75 years, with the longest follow-up being 13 years. In addition, we were able to conduct a sensitivity analysis of studies with a mean follow-up of more than five years.

Contrary to findings of our meta-analysis, previous meta-analyses showed a possible increased overall risk of cancer associated with the use of angiotensin-receptor blockers alone ${ }^{1}$ or combined with ACE inhibitors. ${ }^{2}$ Unlike people who use ACE inhibitors, those who use angiotensin-receptor blockers have high angiotensin II levels. ${ }^{55}$ Moreover, blockage of angiotensin II type 1 receptors by angiotensin-receptor blockers can lead to unapposed stimulation of angiotensin II type 2 receptors, which can lead to tumour angiogenesis. ${ }^{56}$ Such stimulation together with high angiotensin II levels may explain the different results. Unfortunately, because studies included in our analyses mostly reported esti- mates for ACE inhibitor use or for use of either ACE inhibitors or angiotensin-receptor blockers, we were unable to compare the effect of angiotensin-receptor blockers and ACE inhibitors. However, when we analyzed separately the effect of ACE inhibitor use on cancer risk, we found a protective effect in cohort and nested case-control studies as well as in studies with long-term follow-up.

In the subgroup analyses by cancer site, the possible preventive effect of ACE inhibitors or angiotensin-receptor blockers on prostate cancer can be explained in part by the effect of these medications on reducing insulin resistance, ${ }^{57} \mathrm{a}$ known risk factor of prostate cancer. ${ }^{58}$ Regarding smoking-related cancers, the possible smokingdependent effect of the ACE genotype suggested in a few studies ${ }^{59,60}$ may help to explain our finding of a reduced risk of smoking-related cancers associated with long-term use of ACE inhibitors or angiotensin-receptor blockers. Smoking has been shown to increase plasma renin activity and thereby might accelerate the production of angiotensin II to advance carcinogenesis. ${ }^{61} \mathrm{ACE}$ inhibitors or angiotensin-receptor blockers may counteract the cancer-promoting effect of cigarette smoking by reducing the level or activity of overproduced angiotensin II by cigarette smoking.

In our subgroup analyses, we found an increased risk of melanoma and kidney cancer associated with the use of ACE inhibitors or angiotensin-receptor blockers. Some ACE in-

Table 6: Subgroup meta-analyses of association between use of angiotensin-converting-enzyme inhibitor or angiotensin-receptor blocker and risk of cancer

\begin{tabular}{|c|c|c|c|c|c|c|}
\hline Type of cancer & \multicolumn{3}{|c|}{ All studies } & \multicolumn{3}{|c|}{ Cohort studies and nested case-control studies } \\
\hline Any cancer $4,12,13,16,24,29,35$ & $7(4 / 3)$ & $0.85(0.73-0.98)$ & 73.6 & $6(4 / 2)$ & $0.80(0.68-0.95)$ & 74.8 \\
\hline Breast $^{13,18,19,22,24,27,30,31}$ & $8(4 / 4)$ & $0.99(0.90-1.08)$ & 0.0 & $6(4 / 2)$ & $0.98(0.89-1.09)$ & 0.0 \\
\hline Stomach ${ }^{16,23}$ & $2(1 / 1)$ & $0.84(0.52-1.37)$ & 60.1 & $2(1 / 1)$ & $0.84(0.52-1.37)$ & 60.1 \\
\hline Colon/rectum ${ }^{13,24,25,27}$ & $4(1 / 3)$ & $0.98(0.82-1.16)$ & 0.0 & $2(1 / 1)$ & $0.97(0.77-1.22)$ & 0.0 \\
\hline Kidney $y^{9,11,13,24,28,34}$ & $6(1 / 5)$ & $1.50(1.01-2.23)$ & 35.3 & $2(1 / 1)$ & $0.75(0.34-1.66)$ & 27.5 \\
\hline Prostate $^{10,13,15,20,21,24,27,33}$ & $8(3 / 5)$ & $1.00(0.87-1.16)$ & 68.5 & $5(3 / 2)$ & $0.88(0.80-0.97)$ & 0.0 \\
\hline $\begin{array}{l}\text { Smoking-related } \\
\text { cancer }{ }^{* 9,11-13,16,23,24,27,28}\end{array}$ & $9(2 / 7)$ & $1.04(0.77-1.40)$ & 58.1 & $5(2 / 3)$ & $0.86(0.64-1.16)$ & 50.2 \\
\hline
\end{tabular}


hibitors have known photosensitizing properties, ${ }^{62}$ which may enhance photo damage to the skin by ultraviolet radiation and thereby increase the risk of skin cancer ${ }^{63}$ Among studies reporting kidney cancer risk, cohort and nested casecontrol studies ${ }^{23,24}$ compared users of ACE inhibitors with patients with hypertension taking other medications, whereas conventional casecontrol studies led to no significant association between risk of kidney cancer and use of ACE inhibitors or angiotensin-receptor blockers. Therefore, a likely explanation for our finding may be that hypertension itself increased the risk of kidney cancer, an inference supported by several epidemiologic studies. ${ }^{9,64,65}$

\section{Limitations}

Our study has limitations. First, because the quality of our study depends on the data from the original publications used in our meta-analyses, our study may have inherited some problems of potential bias and confounding effects of observational studies. Second, our result may have been confounded by health-seeking behaviour. People who seek care for an asymptomatic condition such as hypertension may be healthier than those who do not seek care. In addition, users of ACE inhibitors or angiotensin-receptor blockers may be more likely to change their unhealthy behaviours and be more health conscious once they become aware of their cardiovascular risk factors. Lastly, the findings regarding individual cancers may be an artifact of multiple comparisons given the inconsistent associations observed.

\section{Conclusion}

No significant association was found between the use of ACE inhibitors or angiotensin-receptor blockers and overall risk of cancer. A possible beneficial effect associated with use of either medication was suggested in sensitivity analyses, including those of studies with long-term follow-up. Large randomized controlled trials with long-term follow-up are needed to specifically test the effect of each of these medications on the risk of cancer.

\section{References}

1. Sipahi I, Debanne SM, Rowland DY, et al. Angiotensin-receptor blockade and risk of cancer: meta-analysis of randomised controlled trials. Lancet Oncol 2010;11:627-36.

2. Bangalore S, Kumar S, Kjeldsen SE, et al. Antihypertensive drugs and risk of cancer: network meta-analyses and trial sequential analyses of 324,168 participants from randomised trials. Lancet Oncol 2011;12:65-82

3. Lindholm LH, Carlberg B. Blood-pressure drugs and cancer: Much ado about nothing? Lancet Oncol 2011;12:6-8.

4. Lever AF, Hole DJ, Gillis CR, et al. Do inhibitors of angiotensin-I-converting enzyme protect against risk of cancer? Lancet 1998;352:179-84

5. Koomen ER, Herings RM, Guchelaar HJ, et al. Melanoma incidence and exposure to angiotensin-converting enzyme inhibitors and angiotensin receptor blockers. Cancer Epidemiol 2009; $33: 391-5$
6. Houben MP, Coebergh JW, Herings RM, et al. The association between antihypertensive drugs and glioma. Br J Cancer 2006; 94:752-6.

7. Pogoda JM, Katz J, McKean-Cowdin R, et al. Prescription drug use and risk of acute myeloid leukemia by French-AmericanBritish subtype: results from a Los Angeles County case-control study. Int J Cancer 2005;114:634-8.

8. Meier CR, Derby LE, Jick SS, et al. Angiotensin-converting enzyme inhibitors, calcium channel blockers, and breast cancer. Arch Intern Med 2000;160:349-53.

9. Shapiro JA, Williams MA, Weiss NS, et al. Hypertension, antihypertensive medication use, and risk of renal cell carcinoma. Am J Epidemiol 1999;149:521-30.

10. Vezina RM, Lesko SM, Rosenberg L, et al. Calcium channel blocker use and the risk of prostate cancer. Am J Hypertens 1998;11:1420-5

11. McLaughlin JK, Chow WH, Mandel JS, et al. International renal-cell cancer study. VIII. Role of diuretics, other anti-hypertensive medications and hypertension. Int J Cancer 1995;63: 216-21.

12. Jick H, Jick S, Derby LE, et al. Calcium-channel blockers and risk of cancer. Lancet 1997;349:525-8.

13. Rosenberg L, Rao RS, Palmer JR, et al. Calcium channel blockers and the risk of cancer. JAMA 1998;279:1000-4.

14. Stahl M, Bulpitt CJ, Palmer AJ, et al. Calcium channel blockers, ACE inhibitors, and the risk of cancer in hypertensive patients: a report from the Department of Health Hypertension Care Computing Project (DHCCP). J Hum Hypertens 2000;14:299-304.

15. Fitzpatrick AL, Daling JR, Furberg CD, et al. Hypertension, heart rate, use of antihypertensives, and incident prostate cancer. Ann Epidemiol 2001;11:534-42.

16. Friis S, Sorensen HT, Mellemkjaer L, et al. Angiotensinconverting enzyme inhibitors and the risk of cancer: a population-based cohort study in Denmark. Cancer 2001;92:2462-70.

17. Lindholm LH, Anderson H, Ekbom T, et al. Relation between drug treatment and cancer in hypertensives in the Swedish Trial in Old Patients with Hypertension 2: a 5-year, prospective, randomised, controlled trial. Lancet 2001;358:539-44.

18. Li CI, Malone KE, Weiss NS, et al. Relation between use of antihypertensive medications and risk of breast carcinoma among women ages 65-79 years. Cancer 2003;98:1504-13.

19. González-Perez A, Ronquist G, Garcia Rodriguez LA. Breast cancer incidence and use of antihypertensive medication in women. Pharmacoepidemiol Drug Saf 2004;13:581-5.

20. Perron L, Bairati I, Harel F, et al. Antihypertensive drug use and the risk of prostate cancer (Canada). Cancer Causes Control 2004; $15: 535-41$.

21. Ronquist G, Rodriguez LA, Ruigomez A, et al. Association between captopril, other antihypertensive drugs and risk of prostate cancer. Prostate 2004:58:50-6.

22. Fryzek JP, Poulsen AH, Lipworth L, et al. A cohort study of antihypertensive medication use and breast cancer among Danish women. Breast Cancer Res Treat 2006;97:231-6.

23. Sjoberg T, Garcia Rodriguez LA, Lindblad M. Angiotensinconverting enzyme inhibitors and risk of esophageal and gastric cancer: a nested case-control study. Clin Gastroenterol Hepatol 2007:5:1160-1166.e1.

24. Assimes TL, Elstein E, Langleben A, et al. Long-term use of antihypertensive drugs and risk of cancer. Pharmacoepidemiol Drug Saf 2008; 17:1039-49.

25. Boudreau DM, Koehler E, Rulyak SJ, et al. Cardiovascular medication use and risk for colorectal cancer. Cancer Epidemiol Biomarkers Prev 2008;17:3076-80.

26. Christian JB, Lapane KL, Hume AL, et al. Association of ACE inhibitors and angiotensin receptor blockers with keratinocyte cancer prevention in the randomized VATTC trial. J Natl Cancer Inst 2008;100:1223-32.

27. van der Knaap R, Siemes C, Coebergh JW, et al. Reninangiotensin system inhibitors, angiotensin I-converting enzyme gene insertion/deletion polymorphism, and cancer: the Rotterdam Study. Cancer 2008;112:748-57.

28. Mellemgaard A, Niwa S, Mehl ES, et al. Risk factors for renal cell carcinoma in Denmark: role of medication and medical history. Int J Epidemiol 1994;23:923-30.

29. Pahor M, Guralnik JM, Salive ME, et al. Do calcium channel blockers increase the risk of cancer? Am J Hypertens 1996;9: 695-9.

30. Fitzpatrick AL, Daling JR, Furberg CD, et al. Use of calcium channel blockers and breast carcinoma risk in postmenopausal women. Cancer 1997;80:1438-47.

31. Largent JA, Bernstein L, Horn-Ross PL, et al. Hypertension, antihypertensive medication use, and breast cancer risk in the California teachers study cohort. Cancer Causes Control 2010; $21: 1615-24$ 
32. Kaae J, Boyd HA, Hansen AV, et al. Photosensitizing medication use and risk of skin cancer. Cancer Epidemiol Biomarkers Prev 2010;19:2942-9.

33. Rodriguez C, Jacobs EJ, Deka A, et al. Use of blood-pressurelowering medication and risk of prostate cancer in the Cancer Prevention Study II Nutrition Cohort. Cancer Causes Control 2009;20:671-9.

34. Fryzek JP, Poulsen AH, Johnsen SP, et al. A cohort study of antihypertensive treatments and risk of renal cell cancer. Br J Cancer 2005;92:1302-6.

35. Yang X, Ma RC, So WY, et al. White blood cell count and renin-angiotensin system inhibitors for the risk of cancer in type 2 diabetes. Diabetes Res Clin Pract 2010;87:117-25.

36. Rothman KJ, Greenland S, Lash TL. Modern epidemiology. 3rd ed. Philadelphia (PA): Lippincott Williams and Wilkins; 2009.

37. DerSimonian R, Laird N. Meta-analysis in clinical trials. Control Clin Trials 1986; 7:177-88.

38. Ernster VL. Nested case-control studies. Prev Med 1994;23: 587-90.

39. Yun YH, Jung KW, Bae J-M, et al. Cigarette smoking and cancer incidence risk in adult men: National Health Insurance Corporation Study. Cancer Detect Prev 2005;29:15-24.

40. Doll R, Peto R, Wheatley K, et al. Mortality in relation to smoking: 40 years' observations on male British doctors. BMJ. 1994;309:901-911.

41. Kahn HA. The Dorn study of smoking and mortality among U.S. veterans: report on eight and one-half years of observation. Natl Cancer Inst Monogr 1966;19:1-125.

42. Lindberg H, Nielsen D, Jensen BV, et al. Angiotensin converting enzyme inhibitors for cancer treatment? Acta Oncol 2004; 43:142-52.

43. Hanif K, Bid HK, Konwar R. Reinventing the ACE inhibitors: some old and new implications of ACE inhibition. Hypertens Res 2010;33:11-21.

44. Ager EI, Neo J, Christophi C. The renin-angiotensin system and malignancy. Carcinogenesis 2008;29:1675-84.

45. Kawahara Y, Sunako M, Tsuda T, et al. Angiotensin-II induces expression of the C-FOS gene though protein kinase-C activation and calcium-ion mobilization in cultured vascular smoothmuscle cells. Biochem Biophys Res Commun 1988;150:52-9.

46. Deshayes F, Nahmias C. Angiotensin receptors: A new role in cancer? Trends Endocrinol Metab 2005;16:293-9.

47. Nogueira EF, Vargas CA, Otis M, et al. Angiotensin-II acute regulation of rapid response genes in human, bovine, and rat adrenocortical cells. J Mol Endocrinol 2007;39:365-74.

48. Guarino M. Epithelial-mesenchymal transition and tumour invasion. Int J Biochem Cell Biol 2007;39:2153-60.

49. Kwon S, Munroe X, Crawley SC, et al. Expression of connective tissue growth factor in pancreatic cancer cell lines. Int $J$ Oncol 2007;31:693-703.

50. Ribatti D, Conconi MT, Nussdorfer GG. Nonclassic endogenous novel regulators of angiogenesis Pharmacol Rev 2007;59:185-205.

51. Volpert OV, Ward WF, Lingen MW, et al. Captopril inhibits angiogenesis and slows the growth of experimental tumors in rats. J Clin Invest 1996;98:671-9.

52. Hii SI, Nicol DL, Gotley DC, et al. Captopril inhibits tumour growth in a xenograft model of human renal cell carcinoma. $\mathrm{Br} J$ Cancer 1998;77:880-3

53. Neo JH, Malcontenti-Wilson C, Muralidharan V, et al. Effect of ACE inhibitors and angiotensin II receptor antagonists in a mouse model of colorectal cancer liver metastases. J Gastro enterol Hepatol 2007; 22:577-84.

54. Meredith PA, McInnes GT. Angiotensin-receptor blockade, cancer, and concerns. Lancet Oncol 2010;11:819.

55. Levy BI. How to explain the differences between renin angiotensin system modulators. Am J Hypertens 2005;18:134S-41S.
56. Walther T, Menrad A, Orzechowski H-D, et al. Differential regulation of in vivo angiogenesis by angiotensin II receptors. FASEB J 2003;17:2061-7.

57. Perkins JM, Davis SN. The renin-angiotensin-aldosterone system: a pivotal role in insulin sensitivity and glycemic control. Curr Opin Endocrinol Diabetes Obes. 2008;15:147-52.

58. Albanes D, Weinstein SJ, Wright ME, et al. Serum insulin, glucose, indices of insulin resistance, and risk of prostate cancer. J Natl Cancer Inst 2009;101:1272-9.

59. Arias-Vásquez A, Sayed-Tabatabaei FA, Schut AFC, et al. Angiotensin converting enzyme gene, smoking and mortality in a population-based study. Eur J Clin Invest 2005;35:444-9.

60. Arima Ha, Kiyohara Ya, Tanizaki Ya, et al. Angiotensin Iconverting enzyme gene polymorphism modifies the smokingcancer association: the Hisayama Study. Eur J Cancer Prev 2006;15:196-201.

61. Laustiola KE, Lassila R, Nurmi AK. Enhanced activation of the renin-angiotensin-aldosterone system in chronic cigarette smokers: a study of monozygotic twin pairs discordant for smoking. Clin Pharmacol Ther 1988;44:426-30.

62. Litt JZ. Drug eruption reference manual. 15 th ed. New York (NY): Informa Healthcare; 2009.

63. Stern RS. Photocarcinogenicity of drugs. Toxicol Lett 1998;102103:389-92.

64. Grove JS, Nomura A, Severon RK, et al. The association of blood pressure with cancer incidence in a prospective study. Am J Epidemiol 1991;134:942-7.

65. McLaughlin JK, Lipworth L. Epidemiologic aspects of renal cell cancer. Semin Oncol 2000;27:115-23.

Affiliations: From the Seoul National University College of Medicine (Yoon, Yang, Jeon), Seoul, Republic of Korea; Hwasung Public Health Center (Yoon), Hwasung, Republic of Korea; Muju Health Center and County Hospital (Yang), Muju, Republic of Korea; the Korea Health Promotion Foundation (Jeon), Seoul, Republic of Korea; the Health Screening Center (Chang), Kangbuk Samsung Hospital, Sungkyunkwan University School of Medicine, Seoul, Republic of Korea; and the Department of Family Medicine (Park), Seoul National University Hospital, Seoul National University College of Medicine, Seoul, Republic of Korea

Contributors: Chan Yoon was responsible for the study design, the acquisition, extraction and interpretation of the data, statistical analysis and drafting and critically revising the manuscript. Hyun-Sik Yang was responsible for the acquisition, extraction and interpretation of the data and critical revision of the manuscript. Inpyo Jeon was responsible for the acquisition and interpretation of the data and critical revision of the manuscript. Yoosoo Chang was responsible for providing insight into the statistical methods and contributed to the interpretation of the data and critical revision of the manuscript. Sang Min Park was responsible for the conception and design of the study, the interpretation of the data, and critical revision of the manuscript. All of the authors approved the final version of the manuscript submitted for publication.

Funding: This research was supported by the Basic Science Research Program of the National Research Foundation of Korea (grant no. 2011-0005475), which is funded by the Ministry of Education, Science, and Technology of the Korean Government. 